\title{
Ойратская рукопись «Шастра под названием “Золотые четки храбрости”, сочиненная наставником Падамбой» из фонда Национального музея Тувы"
}

\author{
Евгений В. Бембеев
}

Калмыцкий научный центр Российской академии наук, Российская Федерация

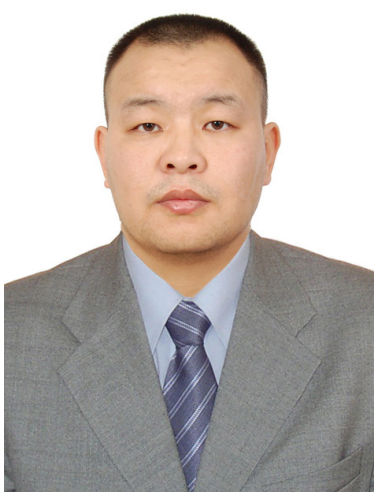

В статье вводится в научный оборот текст ойратского наказа-пророчества «Шастра под названием “Золотые четки храбрости”, сочиненная наставником Падамбой» ("Getülgeqči Padambayin zokoqsan zörögiyin altan erikin kemekü šaštir örošiboi»), который хранится в собрании монгольских рукописей Национального музея Республики Тува. Предполагается, что автором данного поучения может быть известный индийский наставник Падампа Сангье (тиб. phadampa sangs rgyas), или Дампа Сангье (тиб. dатра sangs rgyas).

Приводится транслитерация ойратского рукописного текста, снабженная параллельным переводом на русский язык.

Несмотря на существующие монголографичные и ойратские списки этой шастры, она остается неизвестной исследователям. Лингвистическое описание памятника показывает, что представленный ойратский текст ориентирован на классический ойратский язык, с эпизодичными элементами старописьменного монгольского языка.

Наличие данной рукописи в Туве свидетельствует о широком распространении тибето-монгольской буддийской традиции в республике.

Ключевые слова: ойратская рукопись; наказы; пророчества; шастра; Падамба; буддизм; перевод; архив; Национальный музей Тувы; Тува

"Исследование проведено в рамках государственной субсидии - проект «Устное и письменное наследие монгольских народов России, Монголии и Китая: трансграничные традиции и взаимодействия» (регистрационный номер АAАA-A19-119011490036-1).

Для цитирования:

Бембеев Е. В. Ойратская рукопись «Шастра под названием “Золотые четки храбрости”, сочиненная наставником Падамбой» из фонда Национального музея Тувы [Электронный ресурс] // Новые исследования Тувы. 2019, № 4. URL: https://nit.tuva.asia/nit/article/view/880 (дата обращения: дд.мм.гг.). DOI: 10.25178/nit.2019.4.4

Бембеев Евгений Владимирович - кандидат филологических наук, старший научный сотрудник отдела монгольской филологии Калмыцкого научного центра Российской академии наук. Адрес: 358000, Россия, г. Элиста, ул. И. К. Илишкина, д. 8. Тел.:+7 (847) 223-55-06. Эл. адрес: galdma@yandex.ru ORCID ID: 0000-0001-9936-221X

Bembeev Evgeni Vladimirovich, Candidate of Philology, Senior Research Associate, Department of Mongolian Philology, Kalmyk Scientific Center of the Russian Academy of Sciences. Postal address: 8 Ilishkin St., Elista 358000 Russian Federation. Tel.: +7 (847) 223-55-06.E-mail: galdma@yandex.ru 


\title{
The Shastra Titled 'A Golden Rosary of Courage' Composed by Teacher Padamba: an Oirat manuscript from the National Museum of Tuva"
}

\author{
Evgeni V. Bembeev, \\ Kalmyk Scientific Center of the Russian Academy of Sciences, Russian Federation
}

\begin{abstract}
This article introduces into scientific circulation the Oirat text of The Shastra Titled 'A Golden Rosary of Courage' Composed by Teacher Padamba (Oir. 'Getülgeqči Padambayin zokoqsan zörögiyin altan erikin kemekü šaštir örošiboi') contained in the Mongolian Manuscript Collection of the National Museum of the Tyva Republic. It is believed that the work may have been authored by the famous Indian teacher Padampa Sangye (Tib. Phadampa sangs rgyas), or Dampa Sangye (Tib. Dampa sangs rgyas).

The paper provides a transliteration of the Oirat manuscript accompanied by a parallel Russian translation.

Despite there are a number of Mongol-graphic and Oirat-language copies of this shastra, it remains unknown to researchers. The linguistic description of the monument shows that the examined Oirat text is a sample of the classical Oirat language, with episodic elements of Classical Mongolian.
\end{abstract}

The presence of the manuscript in Tuva evidences the wide spread of the Tibetan-Mongolian Buddhist tradition in the republic.

Keywords: Oirat manuscript; precepts; prophecies; shastra; Padamba; Buddhism; translation; archives; National Museum of Tuva; Tuva

"The reported study was funded by government subsidy - project name 'Oral and Written Heritage of the Mongolic Peoples of Russia, Mongolia and China: Cross-Border Traditions and Interactions’ (registration number AAAA-A19-119011490036-1).

\section{For citation:}

Bembeev E. V. The Shastra Titled 'A Golden Rosary of Courage' Composed by Teacher Padamba: an Oirat manuscript from the National Museum of Tuva. The New Research of Tuva, 2019, no. 4 [online] Available at: https://nit.tuva.asia/nit/ article/view/880 (access date ... ). DOI: 10.25178/nit.2019.4.4

\section{Введение}

Одними из интересных по своему содержанию произведениями старописьменной монгольской литературы являются тексты, в содержании которых присутствуют как пророчества, так и наказы, наставления. Подобные сочинения, авторами которых выступают сам Будда, другие будды и бодхисаттвы буддийского пантеона, а также великие учителя буддизма, имели широкое распространение. Немалое количество памятников такого содержания зафиксировано в ойратской письменной традиции. Среди таких текстов, которые широко бытовали в старописьменной монгольской и ойратской литературах, следует указать на следующие произведения: «Наказ Всеведающего» («Xатugi ayiladuqčiyin zarliq»), «Наказ Чингис-хана, Богдо гегена и Эрдени Сакъя Панчен богдо» («С̌ingges xān Boqdo gegēn Erdeni Sakya bančin boqdoyin zarliq»), «Письмо-наказ Богдо Далай-ламы» («Boqdo Dalai blamayin zarliq bičiq»), «Наказы Хонгшим бодхисатвы и Будды Милы» («Xongšim bodhisadv Mila хоyoroyin zarliq orošiboi») и др. (Бичеев, 2003; Меняев, 2016).

В отечественном монголоведении нет общепринятого термина для обозначения такого рода письменных памятников. Некоторые исследователи трактуют их как «наказы» (Сазыкин, 2001), «письмо-наказ» (Меняев, 2016), другие - «пророчества», «предсказания» (Музраева, 2009; Омакаева, 1995), третьи - «посланиями» (Гедеева, 2011). Вызвано это в первую очередь неоднородностью содержания такого вида произведений. Более приемлемым обозначением для таких неоднородных текстов, в содержании которых присутствует как пророчества, так и связанные с ними наставления, по нашему мнению, является термин «наказы-пророчества».

Архив Национального музея им. Алдан-Маадыр Республики Тыва (далее - НM РТ) располагает большой и уникальной коллекцией монгольских рукописей и ксилографов, которая по сведениям известного ученого-монголоведа А. Г. Сазыкина насчитывает 938 единиц хранения (Сазыкин, 1992: 
45). Наличие в архиве НМ РТ столь огромного количества монгольских рукописей объясняется тем, что основную часть «составили материалы, поступившие из существовавших прежде на территории Тувы буддийских монастырей» (там же: 49-50). Как известно тибетский буддизм в Туву проник через Монголию в Цинский период (вторая половина XVIII - начало XX в.), который «в истории Тувы оказался наиболее благоприятным для становления тувинского варианта буддизма» (Монгуш, 2001: 180). Между тем интересен тот факт, что, несмотря на сопредельные территории и близкие контактные зоны тувинцев с ойратскими этническими группами, из всего рукописного фонда «ойратская часть включает всего восемь рукописей, написанных заяпандитовским “ясным письмом” (Сазыкин, 1992: 45). Отчасти это можно объяснить тем, что в период распространения и укрепления буддийской традиции в Туве, ойратское «ясное письмо» постепенно утрачивало свои позиции даже среди ойратов западной Монголии, где предпочтения отдавались традиционному монгольскому письму.

Одним из двух текстов дидактического содержания, которые хранятся в коллекции НМ РТ, является ойратская рукопись под названием «Шастра под названием “Золотые четки”, сочиненная наставником Падамбой» («Getülgeqči Padambayin zokoqsan zörögiyin altan erikin kemekü šaštir örošiboi», M-280). А. Г. Сазыкин пишет, что в собрании НМ РТ есть «поучения Падма Самбхавы, написанные в

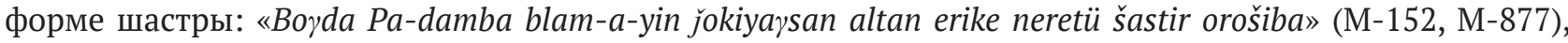
и его проповедь о вреде пьянства: «Arikin-u namtar nomlaysan šašitar orošiba» (M-90, M-91, M-92, M-93, М-145)» (Сазыкин, 1992: 53-54).

Падма Самбхава (717-762 гг.) - великий индийский учитель, известный в Тибете также как Гуруринпоче. Хотя в других монгольских переводах сочинений этого автора его имя обозначено как Badma

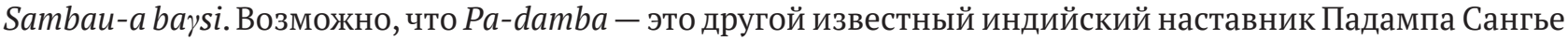
(тиб. phadampa sangs rgyas), или Дампа Сангье (тиб. dampa sangs rgyas).

Известно, что Падампа посещал Тибет неоднократно (последний раз в 1097 г.). В Тибете он распространил учение Шичже (тиб. zhi byed, или sdugb sngal zhi byed), известное как «Умиротворение страданий». Согласно традиции буддизма, это учение приносит облегчение страданий тем, кто в силу влияний кармы прошлых жизней имеет физические недостатки, терзаем болезнями, нищетой и т. п. Оно дает таким людям возможность практиковать Дугнэл Шичже, или «Учение, облегчающее страдания». Если это действительно так, то название ойратского перевода более точно будет звучать, как «Шастра под названием “Золотые четки храбрости”, сочиненная наставником Падамбой» («Getülgeqči Padambayin zokoqsan zörögiyin altan erikin kemekü šaštir örošiboi»). Такое название действительно соотносится с проповедованным Падамбой тантрическим учением, которое требует мотивированной храбрости для долгого и устойчивого воздействия на свою карму.

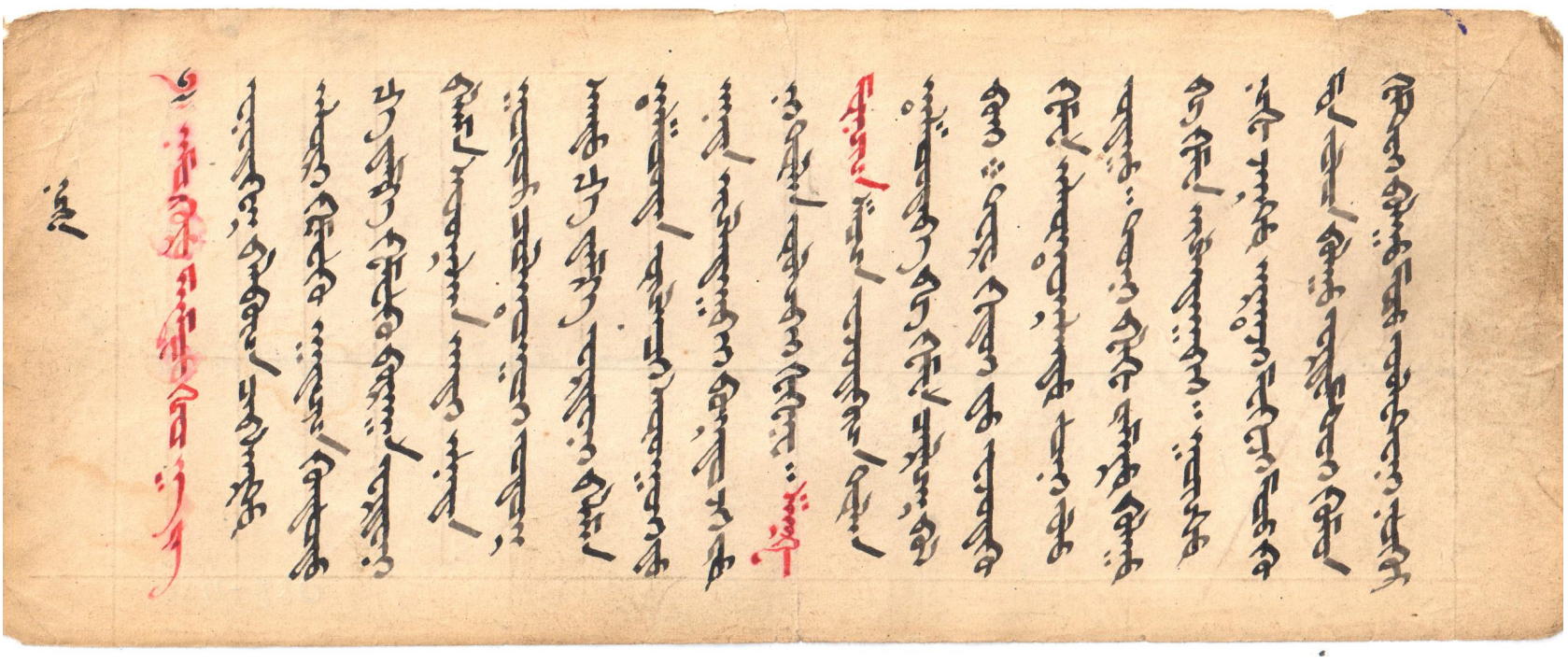

Фото 1. Фотокопия листа 1 рукописи «Шастра под названием “Золотые четки храбрости”, сочиненная наставником Падамбой». Хранится в архиве Национального музея Тувы.

Photo 1. Photocopy of page $1 b$ in the manuscript of "Sastra called "Golden beads of courage" written by the mentor Padamba".

Courtesy of National Museum of Tuva. 
Шастру «Золотые четки храбрости» Падамбы, судя по ее содержанию, скорее следует причислить к наказам-пророчествам, нежели просто к жанру поучений (Сазыкин, 1992: 53). Текст написан в форме диалога между Падамбой и Анандой (Ānada), который вместе с братом Аннурудхой (Andi) пришел навестить учителя, медитировавшего в горах на границе между Тибетом и Непалом.

Увидев его плачущим, Ананда спрашивает его о причине его печали. Учитель поведал о том, что скоро придет время, когда учение Будды придет в упадок. Существуют приметы наступления такого времени, в котором проявятся человеческие пороки, увеличатся грехи и болезни. Он объясняет Ананде причины, по которым это произойдет. Это обычная форма проповеди, в которой пророчества выступают как результат тех деяний, что могут произойти в случае победы зла и греховности над добром и благом. В тексте самого памятника предсказания носят общий характер, как-то: упадок нравственности приведет к тому, что дети не будут почитать родителей; монахи перестанут почитать учителей-наставников; сильный будет угнетать слабого; будет война, брожение умов и т. д. Соответственно спасением от такого явления может стать только твердое следование по пути, проповеданному Буддой.

Рукопись М-280 состоит из 6 листов, пагинация начинается с титульного листа. Название написано на титульном листе. Текст написан черной тушью. Некоторые торжественные слова и выражения выделены красной тушью (namo үuru, Manjughoxaya, Šaqjmuniyin и т. д.).

Текст написан четким почерком, но в то же время в нем наблюдается некоторое количество описок и ошибок. Сразу же необходимо отметить, что для старописьменной ойратской литературы это вполне обычное явление, поскольку единой системы орфоэпических правил не было. Нормы правописания, установленные Зая-пандитой, со временем менялись, поэтому провести границу между описками и умышленными изменениями, внесенными в текст неизвестным переписчиком, не всегда представляется возможным. В этой связи старописьменные источники, представляют большую ценность для исторической грамматики при наличии текстовых материалов, содержащих разные написания слов и морфем, квалифицируемых обычно как грамматические ошибки.

Для наглядности приведем лишь некоторые расхождения и особенности текста шастры Падамбы. Вопервых, необходимо отметить непоследовательное написание слов с орфографической точки зрения. На всем протяжении текста встречается путаница употребления букв $\ddot{u}$ и $u$, $\ddot{u}$ и ӧ: написано usun 'вода' вместо üsün 'волосы', kümugi - вместо kümügi ‘человека' и т. д. Также в тексте памятника встречаются слова без обозначения гласных не первых слогов, а также обратная тенденция, когда в некоторых словах, наоборот, в не первых слогах вставляется «лишняя» гласная: untǰi вместо общепринятого untaji 'спящий', ezelkü вместо ezelekü 'владеть, властвовать'.

Создается впечатление, что переписчик текста не придавал особого значения тому, в каком месте ставить диакритический знак долготы «удан» (или - по другой трактовке - специальной буквы «а/е»). Встречаются примеры таких употреблений: ха̄ үсахи вместо общепринятого хаүсахи 'избавляться',

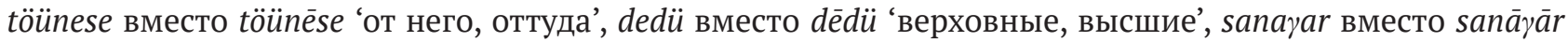
'по своему разумению', yazarasa вместо yazarāsa ‘c той земли’.

При этом в тексте памятника в одних и тех же словах долгота то появляется, то опускается, что связано, скорее всего, с небрежностью переписчика: kemekü / kemēkü ‘называться’. Также встречается пример употребления знака долготы при букве ӥ в слове küтӥйgi 'человека', что является явной ошибкой автора.

В тексте наблюдается употребление ранних ойратских форм ои/ӧ̈, нежели позднеойратских форм ӥ̈̈/uи: үašoudan 'сожаление', тои 'плохой'.

Рассматривая использование служебных морфем, необходимо выделить использование как ранних ойратских форм, например, аффикса возвратного склонения -уе̄n, аффикса творительного падежа

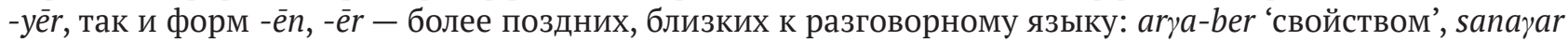
'желанием', yosōr 'по правилам', zasaq-yе̄n 'свою власть', ečigēn 'своего отца'.

В тексте памятнике обнаруживаются две формы условного деепричастия -külē/-xulā и -basu/-besu / -bosu: kemēbesü 'если скажу', bolxulai ‘если будет', nomnoxula ‘если прочитает молитву'. Исследуемый текст показывает регулярное употребление форм на -külēe-xulā, что может косвенно указывать на то, что список сделан, скорее всего, с ойратского первоисточника, так как известно, что использование формы на -külē /-xulā является классическим отличием ойратского письменного языка от старописьменного монгольского, где предпочтение отдается форме на -basu/-besu/-bosu.

Таким образом, представленный ойратский текст ориентирован на классический ойратский язык, с эпизодичными элементами старописьменного монгольского языка. 


\section{Транслитерация и русский перевод}

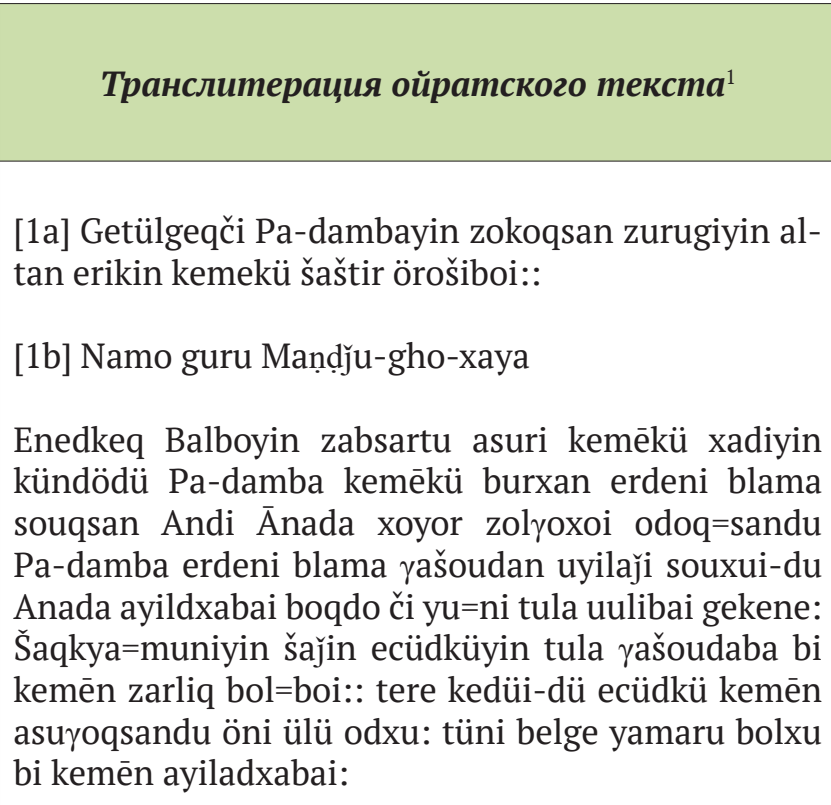

xoyitu nige caqtu aryači meqči mou kü=mün olon bolxu erdemtei kümün gemtei bolxu mou üületeni nökür [2a] gekü: izouri ügei abun ed mal xurāxu: mou yabudaltai kümön doqširxu: sayin sedkil=tei kümündü mou mou nere xadaxu ye=ke ači tusatai kümüni gem-dü oroulxu: yeke kümögi baya kümün ezelekü: xān kümügi xaraca ezelkü: sayin kümün mou kümünei negedekü: itegem ji ü=gei bolun sa[yi]ni geqseni mouyār xariulxu: uruq elgen da[yi] sun bol=xu: amaraq kümön nige nige mekel=kü: suryouli ügei bayitala yekerkēn sedkikü: küqšidiyin süri zalou=ni bolxu: ülü arbidaj̆i bayital bayaj̄ixuyigi küsekü: ese büteq=sen bayitala šidi küsen: idēn=yēn uraq eligeden xadayaloulxu:

\section{Русский перевод²}

[1a] «Шастра под названием “Золотые четки храбрости”, сочиненная наставником ${ }^{3}$ Падамбой»

\section{[1b] Преклоняюсь Манджушри!}

На границе между Индией и Непалом в пещере огромной скалы находился в медитации драгоценный будда-лама Падамба. Когда Анди и Ананда пришли его навестить, то увидели горько плачущего драгоценного будду-ламу Падамбу. Ананада спросил его: «Светлейший, почему ты плачешь?». «Я опечален тем, что религия Будды придет в упадок» - ответил он. «Когда это произойдет?». «Ждать осталось не так долго». «Каковы признаки наступления этого [упадка]?»- спросил [Ананда].

«В будущем будет много плохих людей - хитрых и предприимчивых. Просвещенные станут виновными, а грешников назовут [2а] друзьями. Будут брать [в жены] безродных и заниматься обогащением. Люди неправедного деяния будут свирепствовать. Благонравного объявят плохим, а полезного человека осудят. Небольшая кучка людей будет властвовать над огромной массой. Хан правитель окажется в подчинении простолюдина. Достойные объединятся с недостойными. Не будет доверия, а за добро будут отплачивать злом. Родные станут врагами. Друзья станут обманывать друг друга. Неучи будут проявлять высокомерие. Место старцев займут юнцы. Не будучи рачительными, будут стремиться к обогащению. Не совершая деяний, будут желать чудесного результата. Пропитание будут хранить у родственников.

\footnotetext{
${ }^{1}$ В транслитерации текста использованы следующие условные знаки: знак равенства = ставится в месте переноса части слова на другую строку в рукописи; угловые скобки <...> заключают в себе зачеркнутые автором слова в тексте рукописи; квадратные скобки [ ] заключают в себе восстановленную букву или слово. Подчеркиванием выделены слова, написанные в рукописи красной тушью. В транслитерации текста также использованы пунктуационные знаки: двойное двоеточие - в конце названия произведения и строф, двоеточие - в конце строки.

${ }^{2}$ В тексте перевода в квадратные скобки заключены слова, дополняющие перевод, но отсутствующие в тексте рукописи.

${ }^{3}$ В тексте getülgeqči - букв. Спаситель.
} 


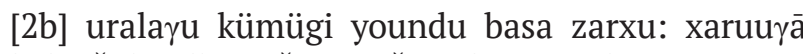
keleqčidü alba tušaxu: ačitai kümegi dayisun metü sanaxu: ečige ekeyin ači ülü sanaxu:ǰiqšikü nayiǰinar erketei bolun ezelekü: noyon kümün xobči kü=mer sayid bolyun törögi tere eb=dekü: buyani üyile-ēce araץa-bēr bultarin xudulčin kümügi ünendü barixu: mekeči kümügi sayin gekü: ire ese gebečigi sangyala

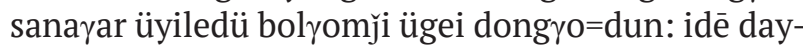
isundun ögün ed sadundu xada kümügi burxandu üzen nomči kü=mügi geteyidü barin nom üyile=düqseni gem bolyon: ečigēn kü=böün mekelkü: amaraq өtör xāya=caxu: xān kümün zasaqyēn ülü xurcadxaxu: nomči kümün tang= $\gamma$ ariq-yēn ülü sakin sonǰil

[3a] ičüri juiqsöüri ügei: ašidā=gi xarān ene nasuni jiryaldu šu=nun: xorōn metü idē eden no=xoyin yabudal-yēr yabun: xoron metü mou sedkil-yer kilencedü ba=yasāxu: ašidiyin nere alduri abaxu idekü-ēce: xudaldun mou üge üne öqči abun <idekü> buyani üyile-ēce arya-bēr zalixalan: öböriyin gemi altan metü sanaxu: ali mou üyile üyiledüqsen-dü tusan olo kürgebečü ötör: mar=tad tusalaqsani xoror xariulxu: xanilxulai moưān kürgen öbörönēn gem arčin: busodin gem delgeröülen:

suryāxola xoritoi tosun tusa=laqsani gem barin: merged-ēce gem $\gamma$ aryān: toyin kümün šaqšavdan

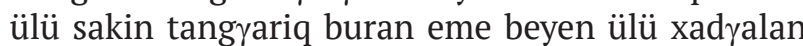
yazarasan usu [3b] tataxu metu: dotōloqsan ügēn busudtu ögölekü: küčütēni kü=čü ügeyen ed mal bul[a]xu: bayan kümün ibüü kümünē gerte gelong metü bolxu: toyin kümün gergei abaxu: köqšin kümün üküküyigi sedkin: muxola a $\gamma a$ bolxu:

nomousan ed kereqlen ünetei erdem üne ü=gei bolon: altan ünetei bolxu: buruu üyile kereqlen edleǰi ülü xangүaxu: untuji ese serin kümün ese kündülen busudi ese kündülebe kememüi: ese bišilran atala bütebe kemen surul üge er=gelkekü ese tanaji bayitala nayirlan ötör ebderekü: yazaraya sana=tāgi dotolon amaraq nöködtön öšikü: teyimi caq bolxudu ša=jin buurxu kemen zarliq bolbo:: : :: [2b] Мастеров заставят делать пустое, говорящих правду подвергать штрафу. Авторитетного человека воспримут как врага, забудут о почитании родителей. Отвратительные друзья обретут власть. Правитель-нойон, назначая сплетника министром, приведет в упадок государство. Лживого человека, уклоняющегося от праведных деяний, назовут праведником, а хитрого - честным. Будут являться без приглашения и громко высказывать свое мнение. Пищу раздадут врагам, а имущество родственникам. Лжеца будут признавать как Будду, а истинного праведника преследовать, деяния его объявят проступком. Сын будет обманывать отца, друзья рассорятся, правитель перестанет следить за строгостью закона.

Монахи перестанут соблюдать обеты, предадутся мирским страстям [3a], не ведая стыда и страха.

Полагая, что они вечны, станут употреблять пищу подобную яду и рыскать как собаки. Отравленные ядом умом будут радоваться греховным деяниям. Ради прославления своего имени, будут выдавать ложь за правду. Уклоняясь от праведных деяний, свои прегрешения будут ценить как золото.

Будут поддерживать неправедные деяния, быстро забыв о совершенной пользе, оплатят злом. На дружбу ответят враждой. Обеляя свои проступки, станут предавать гласности проступки других.

Обучая, окажешься врагом, полезное деяние вменят в проступок, мудрецов объявят виновными. Монахи-тойны, не будучи нравственными, нарушат обеты. Женщины не будут целомудренны. Подобно тому как [3b] достают воду из-под земли тайные помыслы сделают достоянием всех. Сильные станут отбирать имущество у слабых. Богатый в доме бедного человека будет вести себя как гелонг. Тойны будут иметь жен, старые люди будут мечтать о смерти, рабыня станет госпожой.

Монахи будут подвержены наживе. Знание будет не востребовано, золото станет ценностью. Ненасытно будут творить греховные деяния. Находясь в беспробудном сне, не будут уважаемы людьми и будут объявлять, что его не уважают другие. Не практикуя созерцания, станет утверждать, что совершал. Вступая в дружбу с незнакомыми, быстро рассорятся. Скрытно будут мстить друзьям, думающим иначе, чем они. Когда настанет такое время, религия придет в упадок», - поведал [Падамба]. 
anada ayiladxabai teyimi kümünē nököcökü kemen ayiladxaqsandu tei $=[4 \mathrm{a}]$ mi kümünē itegel üge bu zöb=lö: bu zočila üyiledü bu yabuul xor bu kürge üge bu alda: zergedēn bu oroul: ünendü bu ab uruq bu bol: amaraqlaji

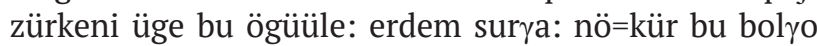
bu daxul: sayidiyin dergede bu yabul: töünese er=dem

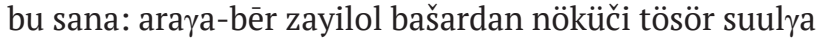

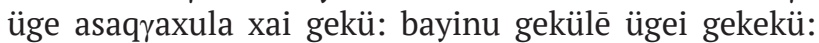
töüni idē ülü iden mal abaxu ügei: töüni kündülüqči bolun ülü maqtan: ülü doromǰi-loxu xāxu bōxu ele bü ülüd: üge bü temecen: külcen öngüröl kemēn zarliq bol=bui:: : ::

teyikele tere kedüi nasuni kemǰindü irekü bi gekenē tabin juirin nasuni kemjindü [4b] irekü kemēbei: teyiküdü burxan bol=xu ündüsün bei buyu kemēn ayilad=xaqsandu: tuuladu eber meleke=dü üsün uryuxu caqtu burxani ündüsün bolxu: teyiküle tere üye=dü nom üyiledečin bi buyu kemeq=sendü: nom üyiledečin olon bol=boču nomiyin yosōr yabučin cōn: ya=sama $\gamma a i$ nom-yēr yabun ed maldu du=ran ügei metü bolun: caq busuyin $\mathrm{i}=\mathrm{dē}$ idel ügei arki gergei tebčimer bolxu: xorun yabuqči olon bolxu: nomiyin darulyan üyiledeyen kemēbe=sü: yertünčiyin nom-ēce xayacaxu kereqtei kemen zarliq bolboi::

teyiküle teyimi nomčin ali yazartu irekü bi gekelēi oi zang yazar=tu irekü bi bolboču olonkin tei=mi bolxu: teyimi nomton tende xa=mi $\gamma$ ai törökü kemeqsendü: usundu orusuqsan enlesen metü uru= [5a] suqsar tamudu törökü kemen nomloboi:: teyikülē teyimi kümündü nom nomloxulā yamāru bolxu kemeqsendü teyimi kümündü nomnoxola kilince xurxoun ündüsün bolxu: nomloq=či töüni demi kelenei gelcemüi: teyikülē dedü blamadu zalbirxula xamiyān törökü kemeqsen-dü zarliq=yār bolxula dēdü töröl olxu: kilince-ēce zayilxula adi cü sedkilden toqtō nom üyiledkü bolxulai töröqsön orondon er=gecekügi tebči uruq eligeni zalyamǰi tasulan ceceq zemis ed=len $\gamma$ adadu oroši görösönē nö=köcöküle amuruulang bolun kišiq delgerekü:: xa xa kemen ineged nom=luyā zokildulxulā sayin aldar yeke bolxu: tegebecü gem olon bui:
Ананда спросил: «Как держать себя с такими людьми?». «С такими [4а] людьми не согласовывай правдивые слова, не ходи к нему в гости, не доверяй им свои дела, не делай им плохо, не проговаривайся возле них, не заводи в свой круг, не верь и не роднись с ними. Будучи в дружеских отношениях не доверяй истинных слов. Не будь ему наставником и не веди за собой, не рекомендуй его в чиновники, не думай научиться от него каким-либо знаниям, найди возможность отстраниться от них и, проявив находчивость, усади их подальше. Если спросишь у него что-либо, ответит: «Ищи». Если спросишь: «Есть ли?», ответит: «Нет». Не ешь его еду, не бери его скот. Выказывай им уважение, но не восхваляй. Не унижай, не препятствуй им. Не вступай с ним в спор, проявляй терпение», - ответил [Падамба].

«На каком году жизни это наступит?» - спросил [Ананда]. «Это наступит через 50-60 [4b] лет», ответил [Падамба]. «Будут ли у них основания стать буддой?» - спросил он. «Когда у зайца вырастут рога, а у лягушки появится шерсть, тогда у них будут основания стать буддой», - ответил [Падамба]. «В такое время будут ли те, кто будет практиковать учение?» - спросил [Ананда]. «Хоть практикующих учение будет много, но тех, кто будет придерживаться истинного учения, будет мало. Следуя модному учению, они будут демонстрировать отречение от материальных благ, будут воздерживаться от приема пищи в неустановленное время, от употребления спиртного и связи с женщинами. Много будет тех, кто будет наносить вред. Если захотят практиковать истинное учение, необходимо отречься от привязанности к мирской жизни», - ответил [учитель].

«В какую страну прибудут такие учителя?» спросил [Ананда]. «Хоть и прибудут в Уй Цзан ${ }^{1}$, но многие будут таковыми». «В какой области обретет рождение такой человек?». «Испытывая страдания, подобно оказавшемуся в воде, [5а] он родится в аду», - ответил он. Тогда [Ананада] спросил: «Что будет если наставлять такого человека?». «Если такого человека наставлять, он заложит основы устранения грехов. Наставляющий будет просвещать скрыто». «Если станет молиться Высшему Учителю, где родится?».

\footnotetext{
${ }^{1}$ Уй Цзан - Тибет.
} 
töü=ni gem yamaru bui kemebēsü: yerü zasaq ceriq atān mökö öbörigi ülü [5b] xarsun busudin üge ülü čingna $=x u$ duran-bēr yabun nomoi zokil=doxu buyan kišiqten cuxaq: bütē=li-yin diyančini kišiq yeke bolun: yertünčiyin nom-yēr yabuqčin olon bolxu: dayisun saduni alaqčixugi tebči-sen blamai-gi olxu berke te=re caqtu tonilxugi küsüqči Yeke nigüülüsüqčii

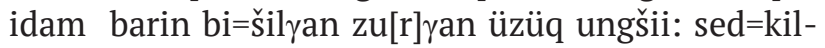
yēn ürgüly̆i töb a youlan nom üyiledüqčin kei cü alaqčilan ülü sedkikü: sayin nere daxal ügei yamāru üyiledbecü bu=sudin tusa sanaxu nom üyile=düqčin öböriyin sedkili öbörön suryoqtun kemen nomloboi:: $:::$

bi xoyitu nasuni küne=sü kereqlen yertüncüyin [6a] dimi üge ögöülküi colo nada ügei yerü kümüni beye olxu ödüyiken zouran erdeni beyē oluqsan-ēce caqtu dēdü nom ese üy=ledkülē öböriyin biyeyin=ki öbörön teneülkü bui::

Getülgeqči Pa-dampayin zokōq=son zörigiyin altan eri=kin kemēkü šašatir dourisabai:: : :::
«Каковы эти препятствия?» - спросил [Ананда]. «Сложно будет практиковать учение, не имея [5b] защиты от враждебного войска и не прислушиваясь к речам других людей. Хоть и много будет практикующих медитацию, но еще больше будет тех, кто будет жить мирской жизнью. Трудно будет найти монаха, который отречется от алчных родных. Тот, кто стремится к просветлению, должен избрать прибежищем Авалокитешвару и начитывать мантру шести слогов ${ }^{1}$.

Держать ум в уравновешенном состоянии и не допускать алчности даже в мыслях. Не стремясь к прославлению, всякое деяние совершать с намерением принести пользу другим существам. Практикующие учение должна сами просвещать свой ум», - сказал [Падамба].

Ради накопления [кармы] для будущего рождения, [6а] у меня нет времени на пустые слова. Если не практиковать высшее учение в период рождения человеком и обретения драгоценного тела, это значит обманывать самого себя.

Шастра под названием “Золотые четки храбрости”, сочиненная наставником Падамбой» закончена.

\section{Заключение}

Необходимо отметить, что одним из выдающихся достоинств собрания Национального музея Республики Тыва является большое число рукописных материалов. Переписывание и распространение рукописных священных текстов являлось важнейшим средством спасения верующих от страданий в грядущих перерождениях. Таким образом, среди рукописей чаще всего можно найти уникальные образцы ойрат-монгольской письменной словесности. Одним из таких, безусловно, является рассмотренная нами ойратская рукопись под названием «Шастра под названием “Золотые четки”, сочиненная наставником Падамбой» («Getülgeqči Padambayin zokoqsan zörögiyin altan erikin kemekü šaštir örošiboi»), которая ярко свидетельствует о широком распространении тибето-монгольской буддийской традиции в Туве. В этой связи введение в научный оборот указанного памятника позволит в дальнейшем проводить сравнительно-сопоставительный анализ письменных источников дидактического содержания, хранящихся в различных уголках буддийского мира.

\section{Благодарности}

Благодарим сотрудников Национального музея им. Алдан-Маадыр Республики Тыва за предоставленную возможность ознакомиться с рукописью данного текста.

\section{СПИСОК ЛИТЕРАТУРЫ}

Бичеев, Б. А. (2003) Этнообразающие доминанты духовной культуры западных монголов (ойратов). Элиста: КалмГУ. 204 с.

Гедеева, Д. Б. (2011) Жанр буддийских посланий в письменной и устной традициях калмыков // «Джангар» и эпические традиции народов Евразии: проблемы исследования и сохранения. Материалы Международной научной конференции / редкол.: Н. Г. Очирова (отв. ред.). Элиста: КИГИ РАН. 174 с. C. 63-66.

${ }^{1}$ Мантра шести слогов - мантра Авалокитешвары - ом мани падме хум. 
Меняев, Б. В. (2016) Буддийские наказы и пророчества в культуре калмыков и ойратов. Факсимиле рукописей. Предисловие, введение, библиогр., транслитер., пер., перелож., глосс., прилож. Б. В. Меняева. Элиста: КалмНЦ РАН. 180 с.

Монгуш, М. В. (2001) История буддизма в Туве. Новосибирск : Наука. 200 с.

Музраева, Д. Н. (2009) О малоизученной ойратской рукописи, именуемой Mila burxani zarliq («Изречения Будды Милы») // Материалы Международной научной конференции «Единая Калмыкия в единой России: через века в будущее», посвященной 400-летию добровольного вхождения калмыцкого народа в состав Российского государства (г. Элиста, 13-18 сентября 2009 г.) : в 2 ч. / редкол.: Н. Г. Очирова (отв. ред.). Элиста : ЗАОр «НПП «Джангар». Ч. ІІ. 648 с. С. 262-266.

Омакаева, Э. У. (1995) Хальмг зурха. Лит. Бурхн шажна мөргүлин ном. Маань болн тәрн. Зәрлг [Калмыцкая астрология. Калмыцкий календарь. Буддийский молитвенник. Заговоры. Предсказания]. Элиста : АПП «Джангар». 176 с. (На калм. яз.).

Сазыкин, А. Г. (1992) Собрание монгольских рукописей и ксилографов из фондов Тувинского республиканского краеведческого музея им. 60 богатырей (Кызыл) // Тюркские и монгольские письменные памятники. Текстологические и культуроведческие аспекты исследования: сборник статей / отв. ред. С. Г. Кляшторный и Ю. А. Петросян. М. : Наука. Восточная литература. 155 с. С. 45-58.

Сазыкин, А. Г. (2001) Каталог монгольских рукописей и ксилографов Института востоковедения РАН : в 3 т. М. Наука. Т. 2.415 с.

Дата поступления: 31.08.2019 2.

\section{REFERENCES}

Bicheev, B. A. (2003) Etnoobrazuiushchie dominanty dukhovnoi kul'tury zapadnykh mongolov (oiratov) [The Western Mongols (Oirats): nation-forming dominants of spiritual culture]. Elista, Kalmyk State University. 204 p. (In Russ.).

Гедеева, Д. Б. (2011) Zhanr buddiiskikh poslanii v pis'mennoi i ustnoi traditsiyakh kalmykov [The genre of Buddhist messages in the written and oral traditions of the Kalmyks]. In: «Dzhangar» $i$ epicheskie traditsii narodov Evrazii: problem issledovaniia i sokhraneniia [Jangar and epic traditions of the Eurasian peoples: issues of research and preservation]. Proceedings of the international scientific conference. Ed. by N. G. Ochirova. Elista, Kalmyk Humanities Research Institute of RAS. 174 p. Pp. 63-66. (In Russ.).

Menyaev, B. V. (2016) Buddiiskie nakazy i prorochestva v kul'ture kalmykov i oiratov. Faksimile rukopisei [Buddhist precepts and prophecies in the culture of Kalmyks and Oirats. Facsimile of manuscripts]. Foreword, introd., bibliogr., transliter., transl., adapt., gloss., appendix by B. V. Menyaev. Elista, Kalmyk Scientific Center of RAS. 180 p. (In Russ.).

Mongush, M. V. (2001) Istoriya buddizma v Tuve [History of Buddhism in Tuva]. Novosibirsk, Nauka. 200 p. (In Russ.).

Muzraeva, D. N. (2009) O maloizuchennoi oiratskoi rukopisi, imenuemoi Mila burxani zarliq («Izrecheniya Buddy Mily») [Revisiting the Oirat manuscript titled Mila burxani zarliq - 'Speeches of Buddha Mila']. In: Edinaya Kalmykiya $v$ edinoi Rossii [United Kalmykia in united Russia]. Proceedings of the international scientific conference celebrating the $400^{\text {th }}$ anniversary of the voluntary entry of the Kalmyks to the Russian State (Elista, September 13-18, 2009). In 2 vols. Ed. by N. G. Ochirova et al. Elista, Dzhangar. Vol. II. 648 p. Pp. 262-266. (In Russ.).

Omakaeva, Eh. U. (1995) Khal'mg zurkha. Lit. Burkhn shazhna mörgülin nom. Maan' boln tärn. Zarlg [Kalmyk astrology. Kalmyk calendar. Buddhist prayer book. Spells. Prophecies]. Elista, Dzhangar. 176 p. (In Kalm.).

Sazykin, A. G. (1992) Sobranie mongol'skikh rukopisei i ksilografov iz fondov Tuvinskogo respublikanskogo kraevedcheskogo muzeia im. 60 bogatyrei (Kyzyl) [Catalogue of Mongolian manuscripts and xylographs housed by the Aldan Maadyr Tuvan Republican Local History and Lore Museum (Kyzyl)]. In: Tyurkskie i mongol'skie pis'mennye pamiatniki. Tekstologicheskie i kul'turovedcheskie aspekty issledovaniia [Turkic and Mongolian written monuments. Textual and cultural aspects of the study]. Collected papers. Ed. by S. G Klyashtorny and Y. A. Petrosyan. Moscow, Vostochnaya Literatura. 155 p. Pp. 45-58. (In Russ.).

Sazykin, A. G. (2001) Katalog mongol'skikh rukopisei i ksilografov Instituta vostokovedeniia RAN [Catalog of Mongolian manuscripts and xylographs housed by the Institute of Oriental Studies of the Russian Academy of Sciences]. In 3 vols. Moscow, Vostochnaya Literatura. Vol. 2. 415 p. (In Russ.).

Submission date: 31.08 .2019 . 